\title{
Assessment of Continuous Oil and Gas Resources in the Ordovician Collingwood Formation and Utica Shale of the Michigan Basin Province, 2019
}

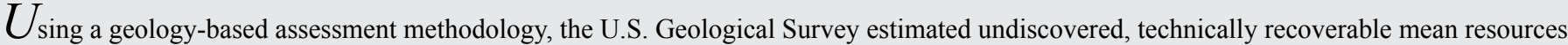
of 290 milllion barrels of shale oil and 7.9 trillion cubic feet of shale gas in the Ordovician Collingwood-Utica Shale Total Petroleum System of the Michigan Basin Province.

\section{Introduction}

The U.S. Geological Survey (USGS) quantitatively assessed the potential for undiscovered, technically recoverable continuous shale-oil and shale-gas resources in the Ordovician Collingwood-Utica Shale Total Petroleum System (TPS) of the Michigan Basin Province (fig. 1). The structural evolution of the intracontinental Michigan Basin may be more complex than its usual depiction as a bowl-shaped depression throughout the early Paleozoic. The basement of the Michigan Basin is partly occupied by an arm of the mid-continent Proterozoic rift system, which contains at least 5,000 feet of Proterozoic synrift sediments (Fisher and Barratt, 1985). The Proterozoic basement, in addition to the rift basin, is highly faulted in a rectilinear pattern, with numerous faults outlining a series of basement horsts and grabens (Fisher and Barratt, 1985; Catacosinos and others, 1990; Ma, 2009). The hypothesis in this study, which follows discussions of basement structure by Fisher and Barratt (1985), Fisher and others (1988), Catacosinos and others (1990), $\mathrm{Ma}$ (2009), and Swezey and others (2015), is that repetitive movement along basement faults is the ultimate cause of the accommodation space and the thermal anomalies that may have been associated with prerift and postrift regimes. The Cambrian to Mississippian sedimentary section is a series of shallow water carbonate, shale, and evaporite sequences separated by regional unconformities. Prerift thermal expansion would have resulted in erosion, and postrift thermal relaxation would create accommodation space. The Upper Ordovician Collingwood Formation is a calcareous marl that was deposited in a basinal setting adjacent to a carbonate platform; the Collingwood is overlain by the Utica Shale, which has a more regional extent in the Michigan Basin Province (Harrison, 2016).

The thermal evolution of the Michigan Basin has been difficult to elucidate for several reasons, including a lack of data from deep wells, an absence of vitrinite from much of the lower Paleozoic section, and conflicting estimates of the scale and timing of erosion across the basin (Cercone, 1984; Gardner and Bray, 1984; Nunn and others, 1984; Vugrinovich, 1988; Wang and others, 1994; Hybza and others, 2018). However, several horizontal wells drilled into the shale of the Collingwood Formation in the central part of the basin produced shale gas, demonstrating that these shales have reached the thermal generation windows for oil and gas (Harrison, 2016) and that gas and perhaps oil have been retained within the Collingwood. This study assessed the potential for shale-oil and shale-gas resources primarily from the shale of the Collingwood Formation, but oil and gas are potentially recoverable from the lower part of the Utica Shale.

\section{Total Petroleum System and Assessment Units}

The USGS defined the Ordovician Collingwood-Utica Shale TPS to encompass potential shale-oil and shale-gas resources primarily within the Ordovician Collingwood Formation with the possible contribution of oil and gas from the lower part of the Utica Shale. The Collingwood-Utica Shale Oil Assessment Unit (AU) and the Collingwood-Utica Shale Gas AU were defined within the TPS based largely on mapping by Harrison (2016). The AUs were defined based on the following criteria: (1) the greater than 20-foot thickness of the shale of the Collingwood Formation; (2) the thermal onset of oil and gas generation at a current depth of about 6,500 feet (Harrison, 2016); and (3) a minimum depth of 2,000 feet for the northern boundary of the Collingwood-Utica Shale Oil AU.

The geologic model underlying the assessment of the Ordovician Collingwood-Utica Shale TPS is for oil to have been generated within the organic-rich Collingwood and the lower part of the Utica Shale. The model further requires that some portion of the oil and gas was retained within the organic-rich shales. Overpressure is present in part of the basin (Gardner and Bray, 1984), but the degree of overpressure in the Collingwood or Utica is not known.

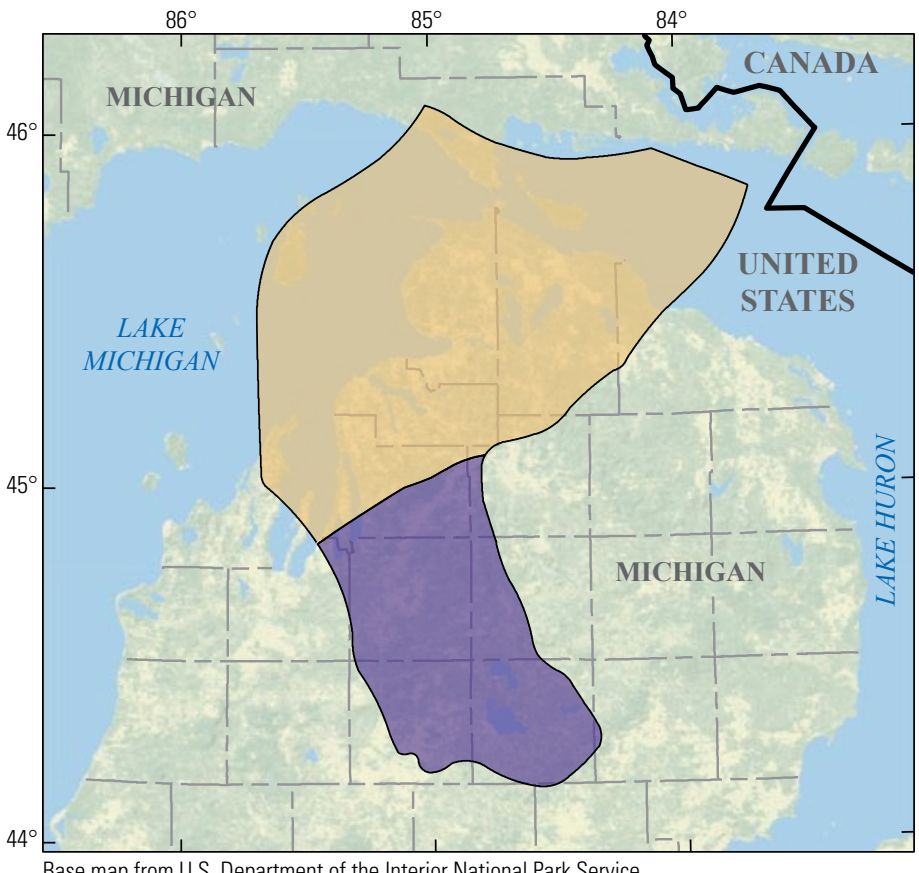

Base map from U.S. Department of the Interior National Park Service

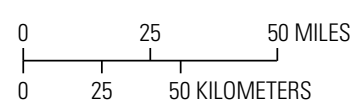

EXPLANATION

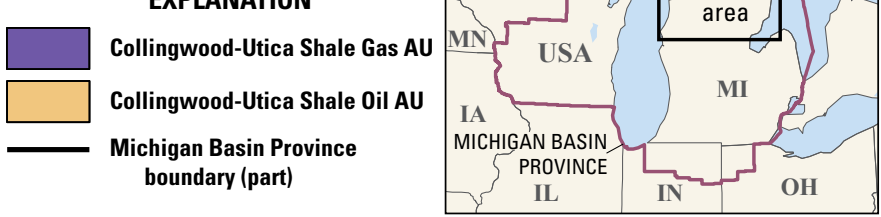

Figure 1. Map showing the location of two continuous assessment units (AUs) in the Michigan Basin Province. The province boundary overlies the border between the United States and Canada. 
Table 1. Key input data for two continuous assessment units in the Ordovician Collingwood-Utica Shale Total Petroleum System of the Michigan Basin Province.

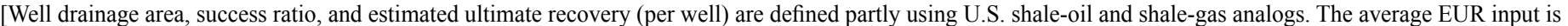

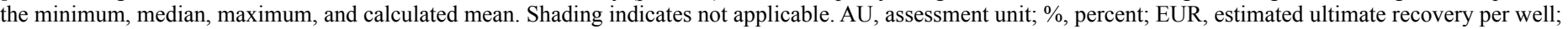
$\mathrm{MMBO}$, million barrels of oil; BCFG, billion cubic feet of gas]

\begin{tabular}{|l|c|c|c|c|c|c|c|c|}
\cline { 2 - 8 } \multicolumn{1}{c}{$\begin{array}{c}\text { Assessment input data- } \\
\text { Continuous AUs }\end{array}$} & \multicolumn{3}{c|}{ Collingwood-Utica Shale Oil AU } & \multicolumn{4}{c|}{ Collingwood-Utica Shale Gas AU } \\
\cline { 2 - 9 } & Minimum & Mode & Maximum & $\begin{array}{c}\text { Calculated } \\
\text { mean }\end{array}$ & Minimum & \multicolumn{1}{c|}{$\begin{array}{c}\text { Mode } \\
\text { Maximum }\end{array}$} & $\begin{array}{c}\text { Calculated } \\
\text { mean }\end{array}$ \\
\hline Potential production area of AU (acres) & 1,000 & 611,000 & $3,088,000$ & $1,233,333$ & 1,000 & 931,000 & $1,862,000$ & 931,333 \\
\hline Average drainage area of wells (acres) & 80 & 120 & 160 & 120 & 80 & 120 & 160 & 120 \\
\hline Untested area in AU (\%) & 100 & 100 & 100 & 100 & 100 & 100 & 100 & 100 \\
\hline Success ratio (\%) & 10 & 50 & 90 & 50 & 40 & 60 & 80 & 60 \\
\hline Average EUR (MMBO, oil; BCFG, gas) & 0.04 & 0.06 & 0.12 & 0.063 & 0.5 & 1.5 & 4.5 & 1.656 \\
\hline AU probability & 0.9 & & & & 1.0 & & \\
\hline
\end{tabular}

Table 2. Results for two continuous assessment units in the Ordovician Collingwood-Utica Shale Total Petroleum System of the Michigan Basin Province. [Results shown are fully risked estimates. F95 represents a 95-percent chance of at least the amount tabulated; other fractiles are defined similarly. Shading indicates not applicable. MMBO, million barrels of oil; BCFG, billion cubic feet of gas; NGL, natural gas liquids; MMBNGL, million barrels of natural gas liquids]

\begin{tabular}{|c|c|c|c|c|c|c|c|c|c|c|c|c|c|c|}
\hline \multirow{3}{*}{$\begin{array}{l}\text { Total petroleum system and } \\
\text { assessment units (AUs) }\end{array}$} & \multirow{3}{*}{$\begin{array}{c}\text { AU } \\
\text { probability }\end{array}$} & \multirow{3}{*}{$\begin{array}{c}\text { Accumulation } \\
\text { type }\end{array}$} & \multicolumn{12}{|c|}{ Total undiscovered resources } \\
\hline & & & \multicolumn{4}{|c|}{ Oil (MMBO) } & \multicolumn{4}{|c|}{ Gas (BCFG) } & \multicolumn{4}{|c|}{ NGL (MMBNGL) } \\
\hline & & & F95 & F50 & F5 & Mean & F95 & F50 & F5 & Mean & F95 & F50 & F5 & Mean \\
\hline \multicolumn{15}{|c|}{ Ordovician Collingwood-Utica Shale Total Petroleum System } \\
\hline Collingwood-Utica Shale Oil AU & 0.9 & Oil & 0 & 239 & 749 & 290 & 0 & 177 & 568 & 217 & 0 & 3 & 9 & 3 \\
\hline Collingwood-Utica Shale Gas AU & 1.0 & Gas & & & & & 2,034 & 6,846 & 15,991 & 7,645 & 27 & 98 & 260 & 114 \\
\hline $\begin{array}{l}\text { Total undiscovered continuous } \\
\text { resources }\end{array}$ & & & 0 & 239 & 749 & 290 & 2,034 & 7,023 & 16,559 & 7,862 & 27 & 101 & 269 & 117 \\
\hline
\end{tabular}

Assessment input data are summarized in table 1. The input data for drainage area, estimated ultimate recovery, and success ratio were guided by the assessment input of the similar age Point Pleasant Formation and Utica Shale in the Appalachian Basin Province (Enomoto and others, 2019).

\section{Undiscovered Resources Summary}

The USGS quantitatively assessed undiscovered continuous shale-oil and shale-gas resources within the Ordovician CollingwoodUtica Shale TPS of the Michigan Basin Province (table 2). The fully risked mean totals are 290 million barrels of oil (MMBO) with an F95-F5 range from 0 to 749 MMBO; 7,862 billion cubic feet of gas (BCFG), or 7.9 trillion cubic feet of gas, with an F95-F5 range from 2,034 to $16,559 \mathrm{BCFG}$; and 117 million barrels of natural gas liquids (MMBNGL) with an F95-F5 range from 27 to 269 MMBNGL. The zero at the F95 fractile reflects risk on geologic elements of the Collingwood-Utica Shale Oil AU.

\section{References Cited}

Catacosinos, P.A., Daniels, P.A., Jr., and Harrison, W.B., III, 1990, Structure, stratigraphy, and petroleum geology of the Michigan basin, chap. 30 of Leighton, M.W., Kolata, D.R., Oltz, D.F., and Eidel, J.J., eds., Interior cratonic basins: American Association of Petroleum Geologists Memoir 51, p. 561-601.

Cercone, K.R., 1984, Thermal history of Michigan basin: The American Association of Petroleum Geologists Bulletin, v. 68, no. 2, p. 130-136.

Enomoto, C.B., Trippi, M.H., Higley, D.K., Drake, R.M., II, Gaswirth, S.B., Mercier, T.J., Brownfield, M.E., Leathers-Miller, H.M., Le, P.A., Marra, K.R., Tennyson, M.E., Woodall, C.A., and Schenk, C.J., 2019, Assessment of undiscovered continuous oil and gas resources in the Upper Ordovician Point Pleasant Formation and Utica Shale of the Appalachian Basin Province, 2019: U.S. Geological Survey Fact Sheet 2019-3044, 2 p.

Fisher, J.H., and Barratt, M.W., 1985, Exploration in Ordovician of central Michigan basin: American Association of Petroleum Geologists Bulletin, v. 69, no. 12, p. 2065-2076.

Fisher, J.H., Barratt, M.W., Droste, J.B., and Shaver, R.H., 1988, Michigan Basin, chap. 13 of Sloss, L.L., ed., Sedimentary cover-North American craton-U.S.: The Geological Society of America, The geology of North America, v. D-2, p. 361-382.

Gardner, W.C., and Bray, E.E., 1984, Oils and source rocks of Niagaran reefs (Silurian) in the Michigan basin, in Palacas, J.G., ed., Petroleum geochemistry and source rock potential of carbonate rocks: American Association of Petroleum Geologists, v. 18. Studies in Geology, p. 33-44.

Harrison, W.B., III, 2016, The Collingwood-Utica Shale in Michigan: Western Michigan University website, accessed September 26, 2019, at https://wmich.edu/ sites/default/files/attachments/u584/2016/Evaluation $\% 20$ of $\% 20$ the $\% 20$ Stratigraphy...Collingwood $\% 20$ Utica $\% 20$ shale $\% 20 \% 28$ Ordovican $\% 29$.pdf.

Hybza, J., Wagenvelt, K., and Kominz, M., 2018, Thermal maturation modeling of the Michigan basin: American Association of Petroleum Geologists, Search and Discovery Article No. 11119, accessed September 27,

2019, at http://www.searchanddiscovery.com/pdfz/documents/2018/ 11119 hybza/ndx_hybza.pdf.html?q=\%252BauthorStrip\%253Ahybza+isMeetingAbstract $\% 253$ Amtgabsyes.

Ma Lin, 2009, Noble gases dissolved in groundwaters of the Michigan BasinImplications for paleoclimatology, hydrogeology, tectonics and mantle geochemistry: Ann Arbor, University of Michigan, Ph.D. dissertation, 229 p., accessed September 27, 2019, at https://deepblue.lib.umich.edu/handle/2027.42/62261.

Nunn, J.A., Sleep, N.H., and Moore, W.E., 1984, Thermal subsidence and generation of hydrocarbons in Michigan basin: The American Association of Petroleum Geologists Bulletin, v. 68, no. 3, p. 296-315.

Swezey, C.S., Hatch, J.R., East, J.A., Hayba, D.O., and Repetski, J.E., 2015, Total petroleum systems of the Michigan Basin-Petroleum geology and geochemistry and assessment of undiscovered resources, chap. 2 of Geologic assessment of undiscovered oil and gas resources of the U.S. portion of the Michigan Basin: U.S. Geological Survey Digital Data Series DDS-69-T, 162 p.

Vugrinovich, R., 1988, Shale compaction in the Michigan Basin-Estimates of former depth of burial and implications for paleogeothermal gradients: Bulletin of Canadian Petroleum Geology, v. 36, no. 1, p. 1-8.

Wang, H.F., Crowley, K.D., and Nadon, G.C., 1994, Thermal history of the Michigan basin from apatite fission-track analysis and vitrinite reflectance, chap. 12 of Ortoleva, P.J., ed., Basin compartments and seals: American Association of Petroleum Geologists Memoir 61, p. 167-177.

Differences in the capitalization of Michigan Basin in the references cited section reflect the original authors' usage.

\section{For More Information}

Assessment results are also available at the USGS Energy Resources Program website at https://energy.usgs.gov.

\section{Michigan Basin Province Assessment Team}

Christopher J. Schenk, Tracey J. Mercier, Cheryl A. Woodall, Heidi M. Leathers-Miller, Thomas M. Finn, Phuong A. Le, Michael E. Brownfield, Kristen R. Marra, and Geoffrey S. Ellis 